Psychology of Language and Communication 2008, Vol. 12, No. 2

DOI: $10.2478 /$ v10057-008-0006-X

\author{
HANNA J. BATORÉO \\ Open University at Lisbon
}

\title{
COGNITIVE AND LEXICAL CHARACTERISTICS OF MOTION IN LIQUID MEDIUM: AQUA-MOTIONVERBS IN TYPOLOGICALLY DIFFERENT LANGUAGES
}

\begin{abstract}
In the present paper we survey the verbs speakers use most frequently to encode the movement of a non-liquid Figure in or on a liquid Ground (AQUA-motion verbs). Our main data come from European Portuguese (EP) (cf. Batoréo, 2007, in press; Batoréo et al., 2007; Casadinho, 2007), and our results are mainly based on non-elicited data from electronically available language corpora of native EP speakers and contrasted with traditional Portuguese dictionary data (cf. Majsak, 2007). The EP results obtained are discussed within a lexical field AQUAmotion, as presented and characterized in Lander, Maisak, \& Rakhilina (2005) and Majsak \& Rahilina (2003, 2007) as well as discussed for some particular languages in Arad (2007) and Divjak \& Lemmens (2007). They are approached also within a broader context of the typology of lexicalization patterns in the sense of Talmy 1985, 2000 (cf. Batoréo, 2000 for EP). The tri-partition proposed for the AQUA-motion field by distinguishing SAILING, SwIMmING and FLOATING verbs will be revisited. Approaching both physical and metaphorical meanings in EP, the contrasts discussed are between the FlOATING verbs 'flutuar' vs. 'boiar' and the SWIMMING one 'nadar', as well as the rich SAILING area with its prototypical verb 'navegar'. The basic parameters to be discussed are: (i) the nature of the moving figure, (ii) the nature of motion (passive vs. active, directed vs. non-directed, motion and containment), (iii) the nature of the metaphorical projection (e.g. AERO-motion and abstract domains), proving that languages may differ in predictable ways not only in grammar but also in lexicon.
\end{abstract}

Key words: AQUA-motion verbs, European Portuguese corpora, typology of lexicalization patterns, metaphorical projection

\section{Introduction}

As a number of studies showed in recent decades (cf. Talmy, 1985, 2000 and Newman 1997, 2000) languages may differ in predictable way not only in grammar but also in lexicon, which means that the differences shown in their lexicon are not arbitrary. In this study, the semantic field of Motion is examined in particular and

The first version of this paper was presented at the 10th International Cognitive Linguistics Conference, Cracow, 2007 as "Lexical typology of AQUA-motion lexicon: The case of European Portuguese". Address for correspondence: Hanna J. Batoréo, Open University at Lisbon, Department of Portuguese Language and Culture, Rua da Escola Politécnica 147, 1269-001 Lisboa, Portugal. E-mail: hanna@univ-ab.pt 
its specific area of being in Motion in liquid medium - AQUA-motion domain - is focused upon.

\section{Motion events and Talmy's lexicalization patterns (Talmy, 1985)}

Motion events can be defined as the movement or location of one entity, the Figure, situated with respect to another entity, the reference object, the Ground (Talmy, 2000, p. 25). The specifics of the Figure and the Ground play a major role in the conceptualisation and linguistic coding of the motion event. Talmy's typological distinction (Talmy, 1985) predicts that Verb-framed languages frame typically the PATH in the Verb, with MANNER or CAUSE optionally expressed in a satellite, as in Romance languages (exs. 1 and 2), whereas Satellite-framed languages express the core schema (MOTION, PATH) in a satellite leaving the verb free to express other co-events (MANNER or CAUSE) as in Germanic (exs. 3a, b) or Slavonic languages (4a, b).

- Verb-framed language: PATH in the Verb + MANNER or CAUSE in a satellite

$\rightarrow$ Romance languages (e. g. Portuguese)

(1) (EP) O foão atravessou o rio a nado.

John crossed the river swimming.

MOTION + PATH in the Verb + MANNER

(2) (EP) ?? * O foão nadou através do rio. John swam across the river

- Satellite-framed languages: MANNER or CAUSE in the Verb + PATH in a satellite

$\rightarrow$ Germanic languages (e.g. English)

$\rightarrow$ Slavonic languages (e.g. Polish)

(3) (a) (Eng.) John swam across the river??

MOTION + MANNER in the Verb + PATH

(b) (Pl) Jan ptynat/przeptynąt przez rzeke

John swam across the river

MOTION + MANNER in the Verb + PATH

(4) (a) (Eng) (*) John crossed the river swimming. 
Figure 1. AQUA-motion basic typology according to Lander, Majsak, \& Rahilina (2005)

\begin{tabular}{|l|l|l|}
\hline (1) SWIMMING & (2) FLOATING & (3) SAILING \\
\hline - humans & - wooden pieces in the sea & - vessels and their pilots \\
- fish & - carrot pieces in the soup & \\
- birds & & \\
\hline
\end{tabular}

(b) (Pl) $\left(^{*}\right)$ Jan przebyt rzeke plynac.

John crossed the river swimming.

In other words, verbs may typically conflate two different concepts, either as [MOTION + PATH] or as [MOTION + MANNER] (Talmy, 1985, 2000).

The subcategorization of Motion can be suggested, focusing on the presence per se of motion or location: (i) Translational Motion, where an object's basic location shifts from one point to another in space, (ii) Self-contained Motion, as in oscillation, rotation, expansion, and local wander, and (iii) Stationary Motion, as in the case of location verbs (cf. Talmy, 2000, II, p. 35).

\section{Typological characteristics of AQUA-motion verbs (Majsak and Rahilina 2003, 2005, and 2007)}

Within the range of Translational Motion three basic domains can be distinguished on the basis of the types of Ground: AQUAMOTION with respect to water (or, by extension, liquids in general), such as related to the verbs 'swim', 'sail' or 'float', AEROMOTION, with respect to air, such as 'fly' or 'hover', and TERRAMOTION with respect to earth, such as 'walk', 'crawl' or 'drive' (Divjak \& Lemmens, 2007)1.

Using relevant information on AQUA-motion expression in more than 40 languages, Majsak and Rahilina (2003, 2005 and 2007) suggest the most basic distinction between the three domains of SWIMMING, SAILING and FLOATING.

This distinction manifests itself more or less consistently in most languages of the sample the authors used by means of lexical oppositions and constraints on interpretation arising in the corresponding contexts. "It should be emphasized once more that this tripartition is by no means descriptive only, since it is based on similarities between unrelated languages. The widespread occurrence of its reflections refers to the fact that it is not arbitrary and perhaps mirrors universal tendencies in conceptualization of aqua-motion.” (Majsak \& Rahilina, 2007, p. 17, our bold).

\footnotetext{
1 "It should be noted that this distinction is pitched at a relatively high level of abstraction distinguishing as ground types AIR, EARTH and WATER (more on ground incorporation into the verb below). Obviously, not all languages carve up the Ground-space in this way: some may make no distinction at all, others may conflate two (e. g., AIR and WATER) and there may even be languages that impose more fine-grained distinctions." (Divjak \& Lemmens, 2007, p. 152).
} 
The SWIMMING domain is typically associated with self-propelled motion of an animate Figure, which presupposes much control and agentivity, as in 'swim' and 'plunge', in English, and 'nadar' (swim) (ex. 5), and also in the "merge" verbs: 'imergir' (immerse),' emergir' (emerge), 'submergir' (submerge), in Portuguese.

(5) (EP) Os homens/os peixes nadam no mar/ no rio. Men/fish swim in the sea/ in the river.

The SAILING domain is typically associated with motion of vessels or people aboard, which presupposes some agentivity, yet this is not always the agentivity of the Figure, as in 'sail' and 'row', in English, and 'navegar' (form: 'nave' (vessel) + INF), 'velejar', 'andar à vela', 'fazer vela', (from: 'vela' (sail)),'marear' (from: 'mar' (sea)), 'fazer surf', 'surfar' (to surf),' remar' (to row), 'vogar', singrar', etc., in Portuguese (exs. 6 and 7).

An interesting feature of these verbs is their capacity to be used both with animate (mainly human) and inanimate Figures (namely vessels), which can be thought of as an instance of the well-known metonymical shift CONTAINER > CONTENTS (exs. 6 and 7).

(6) (EP) Os marinheiros navegam nos mares do sul. Sailors sail in the seas of the south.

(7) (EP) Os barcos navegam nos mares do sul. Ships sail in the seas of the south.

The FLOATING domain reflects the situation of passive, uncontrolled and nonagentive movement in liquid, both within the liquid and on its surface, as in 'flow' and 'drift', in English, and 'flutuar', 'boiar', 'andar à deriva', in Portuguese (ex. 8).

(8) (EP) Os peixes/ os corpos mortos flutuam no rio. Fish/ corpses float in the river.

According to the studies of Majsak \& Rahilina (2007), languages can generally be divided into middle, rich and poor AQUA-motion systems. A system is characterized as middle if it distinguishes between the three types of verbs but does not display any additional oppositions, which is e. g. the case of Persian, Tamil and Maninka. On the other hand, there are languages whose AQUA-motion lexicon is significantly distinct and much more complex and rich than the "middle" ones, namely in standard Indonesian. According to the same authors, Indonesian AQUA-motion verbs can be easily classified into three main groups that correspond to the domains but then richly specified. In the SWIMMING domain there is a neutral verb corresponding to 'swim' and a specific one meaning 'plunge', 'swim under the water'. In the SAILING domain there is a neutral verb 'sail', a means-specified: 'sail on a ship', 'sail on a 
boat', 'sail on a raft', 'row', and place-specified: 'go in a lake', 'go seaward' or 'go in a channel'. All verbs are derived from nominal roots describing either means or place. In the FLOATING domain there is a possibility of strong dynamicity: 'flow with the current' and semidynamicity: 'float', 'drift about (on water)', 'swing to and fro'.

In a poor aqua-system the distinction between the three types of verbs is obscured, made peripheral or neutralized, the situation of many Slavic languages (e.g. Russian or Polish), where a single root supplies all of three domains. The verbs are morphologically related and differ roughly in the iterativity and/or directedness of the process irrespectively of the domain (exs. 9 and 10).

(9) (Pl) Człowiek/ todka/ kloc drzewa ptynie do brzegu. A man/ a boat/a log swims/sails/floats towards the bank.

(10) (Pl) Człowiek/ todka/ kloc drzewa plywa przy brzegu. A man/ a boat / a log is moving to and fro not far from the bank.

\section{Typological specificity of $A Q U A-$ motion verbs in European Portuguese}

In European Portuguese the AQUA-motion lexicon is richer than in the "middle" systems but not as complex as the Indonesian "rich" system illustrated above. European Portuguese AQUA-motion verbs can be easily classified into three main groups, as shown above, but then richly specified in some of them. In the SWIMMING domain there is a neutral verb 'nadar' corresponding to 'swim' and some specific verbs of the "merge" type: 'imergir' (immerse), emergir' (emerge), 'submergir' (submerge), meaning 'plunge', 'swim under the water, etc.'. In the SAILING domain there is a neutral verb 'navegar', meaning 'sail', as in 'sail on a ship', 'sail on a boat', 'sail on a raft', and then some specific verbs such as 'remar' (row), 'velejar'/ 'andar à vela'/ 'fazer vela' (sail on a boat with a sail), 'surfar'/ 'fazer surf' (surf), and some others with very restricted and/or old usages: 'marear', 'vogar', 'singrar'. In the FLOATING domain there are two verbs: 'flutuar' and 'boiar' that can be interchanged quite easily in some contexts and show very few contextual restrictions. Some other verbs like 'sobrenadar' (over + swim) or 'sobreaguar' (over + water + INF) that are still mentioned in some studies on Portuguese AQUA-motion verbs (cf. Majsak 2007) are not confirmed in present day EP usage confirmed by electronic corpora (cf. References).

\section{Physical movement in a liquid Ground}

The SWIMMING domain: (PE) NADAR

In European Portuguese the SWIMMING domain uses typically a neutral verb 'nadar' (swim) (see ex. 5 above) conceptualizing AQUA-motion as self-propelled Motion of an animate Figure, which presupposes much control and agentivity, but no direc- 
tion. As a matter of fact, the most common use of 'nadar' can be interpreted as either directed or non-directed (ex. 11), and only specific contextualization will allow either clearly direction-oriented interpretations. (exs. 12, 13) or non-oriented ones (ex. 14)

(11) Os homens/os peixes nadam no mar/ no rio. Men/ fish swim in the sea/ in the river

(12) O foão atravessou o rio a nado. John crossed the river swimming.

(13) O foão nada na direcção da margem do rio. John swims/ is swimming towards the bank.

(14) O foão nada perto da margem do rio. John swims/ is swimming not far from the bank.

The SAILING domain: (PE) NAVEGAR

In European Portuguese the SAILING domain uses typically the basic verb 'navegar' (see exs. 6 and 7 above), derived from 'nave' (vessel), and approximately a dozen other verbs and verbal analytic expressions (formed typically with light verbs 'andar' (go) and/or 'fazer' (do)), such as 'velejar' (sail, lexicalization of 'vela' (a sail)), 'andar à vela', 'fazer vela', in the sense of 'to sail under sail', to do sailing', 'to go sailing'; 'fazer surf', 'surfar' (to surf/ to do surfing) or' remar' ( row, lexicalization of 'remo' (oar)) (exs. 15 and 16).

(15) Os barcos navegam no alto mar.

Ships sail at sea.

(16) O meu filho veleja/ faz vela/ anda à vela aos fins-de-semana. My son sails/goes sailing at week-ends.

(17) A primeira equipe remou mais depressa e chegou em primeiro lugar. The first team rowed more quickly and arrived in first place.

There are also some other verbs used in this domain with very restricted usage, mainly in some fixed expressions. This is the case of'marear' (lexicalisation of 'mar' (sea)), which is used nearly exclusively in old fixed expressions and/or specific technical contexts referring to navigation, such as 'arte de bem navegar','arte de bem marear' (navigation art), 'mestres de marear' (navigation masters) or 'carta de marear' ('navigation document). Some other verbs as 'singrar' are no more used (or even recognized by native EP speakers) in their physical meaning, being used only metaphorically as in 'singrar na vida' in the sense of to be a winner or to have success in life as a result of hard work against the waves (i.e. obstacles).

The FLOATING domain: (PE) FLUTUAR

In European Portuguese there are two main verbs in the FLOATING domain: 'flutuar' (see ex 8 above) and 'boiar', both referring to passive, uncontrolled 
and non-agentive movement in liquid. In many contexts either can be used interchangeably (ex. 18).

(18) (EP) Os cubos de gelo flutuam/ bóiam na sopa. Ice cubes float in the soup.

'Flutuar' is generally used when Figure is driven by a current and/ or by wind in or on a liquid Ground (as in exs. 8 above, 19 and 20 below) or when the movement implies containment within a liquid (ex. 21).

(19) (EP) As folhas que caíram flutuam (?? boiavam) na poça da água. Fallen leaves float in a puddle.

(20) (EP) A mancha de petróleo flutua (?? boiava) no mar. Oil stain floats in the sea.

(21) (EP) A criança flutuava ( ${ }^{*}$ boiava) no ventre da mãe. The child floated in the mother's womb.

'Boiar', on the other hand, is typically used when maintenance on the surface is implied, especially when preventing drowning is expected (ex. 22).

(22) (EP) As crianças aprenderam a boiar ( ${ }^{*}$ ?flutuar), mas ainda não sabem nadar.

Children learnt how to float butstilldonotknowhow to swim.

When drifting is referred to, an analytical expression 'ficar à deriva' (lit.: to stay adrift) is used (ex. 23).

(23) (EP) Depois do acidente a jangada ficou à deriva durante três dias. After the accident the raft drifted for three days

\section{Metaphorical uses: AERO-motion and abstract movement}

All the AQUA-motion verbs allow typically (a certain degree of) metaphorical uses. Mostly, the key to the metaphorization is the Ground no longer being of a liquid type (e.g. swimming in money, navigating through a crowd, floating currency in finances, etc.).

In poor AQUA-motion systems the basic AQUA-motion verb(s) - such as 'plyt"' and 'plavat", in Russian, or 'pływać' and 'płynacc', in Polish (exs. 24a and 25a), can be extended to refer to almost any smooth movement, gliding or flowing in the air or in an abstract Ground. It describes the smooth motion of clouds or airplanes in the sky, the flow of a crowd of people in the street, of a couple dancing or of music across a ballroom, and even the flow of the course of currency. If 
compared with EP examples, the Polish unique verb can be rendered by different AQUA-motion verb(s) e. g. 'flutuar', navegar', etc. (exs. 24 a and b, 25 a and b).

(24) (a) (Pl) Pani K. ptynęta wwalcu. Mrs. K. swam/ was swimming in a waltz.

(b) Cf. (EP) A senhora K. flutuava a valsar/ quando valsava. Mrs. K. floated/ was floating in a waltz.

(25) (a) (Pl) Wysoko nad lasami ptynęty obtoki wiosenne. Some spring clouds swam/were swimming above the forest.

(b) Cf. (EP) Lá no alto, por cima dos bosques, navegavam/flutuavam as nuvens primaveris.

Some spring clouds sailed/were sailing above the forest floated/were floating.

In European Portuguese different AQUA-motion verbs show different degrees of metaphorization: in the case of 'nadar' we observed only five per cent of metaphoric constructions in our data, whereas in the case of 'flutuar' two-thirds of all the occurrences were metaphorical (!) (cf. Batoréo et al., 2007).

The following motion metaphors occurred in our data with the following EP AQUA-motion verbs:

(i) Smooth movement gliding or flowing $\rightarrow$ 'navegar', 'flutuar', 'nadar' (exs. 26-30):

(26) A bandeira flutua no ar.

A flag floats in the air.

(27) O astronauta flutua no espaço. An astronaut moves in space.

(28) Navegar no ciberspaço. To move in cyberspace.

(29) O politico flutua num barco. A politician floating in his boat.

(30) Flutuar de quarto alugado em quarto alugado. To move on from one rented room to another.

(ii) To gain an understanding in some domain $\rightarrow$ 'navegar', 'nadar' (exs. 31 and 32):

(31) O político navega no alto mar. A politician moves at sea.

(32) $X$ não sabe nadar. $\mathrm{X}$ does not know how to swim. 
(iii) To be submerged in a large quantity of something (e.g. food, clothing, tears, luxury, dreams, blood) in the sense of living in luxury/ abundance of some other substance: $\rightarrow$ 'nadar' (exs. 33 and 34):

(33) Nadar em dinheiro/ riqueza.

Swim in money, richness.

(34) Nadar em sangue.

Swim in blood.

(iv) To thread one's way through some substance (e. g. crowd) $\rightarrow$ 'navegar' (cf. 24b above) (ex. 35):

(35) Navegar em águas turvas.

To move in unclear waters.

(v) To be unstable (e. g. floating currency, a walking floor) $\rightarrow$ 'flutuar' (exs. 36 and 37):

(36) A moeda flutuante.

Floating currency.

(37) Chão flutuante.

Walking floor.

(vi) To appear/ disappear in/out of sight of an observer $\rightarrow$ imergir, emergir, submergir

(38) Emergir da multidão.

Emerge out of the crowd.

\section{Extended AQUA-motion typology (Divjak \& Lemmens, 2007)}

On the basis of the study of AQUA-motion verbs in Dutch (Divjak \& Lemmens, 2007) the authors proposed an extension of the typology presented initially by Majsak and Rahilina (2003, 2005, and 2007) ${ }^{2}$, adding four new areas to the initially analyzed three AQUA-motion domains:

(i) SwIM verbs (prototypical movement of animate beings - 'swim'),

(ii) SAIL verbs (instrument incorporation: motion of vessels/ people on vessels - 'sail') and

(iii) FLOAT verbs (non-controlled/ non-directed location/movement - 'float'). The new domains were:

(iv) Containment (movement within the water - 'hover', 'float'),

2 Divjak \& Lemmens, 2007, p. 155, Table I. 
(v) MERSION (up/down movement up/down of water - 'dive', 'sink'),

(vi) SPlatter (movement which makes water move as well - 'splash'),

(VII) FLOW (movement of water itself - 'stream').

Our EP data (cf. References) show relevance of at least three of these new proposals - CONTAINMENT, MERsion and Flow:

- In some uses of 'flutuar' (but not 'boiar') the conceptualization of CONTAINMENT is obligatory, as in ex. (21);

- The "merge" kind of verbs indicating Mersion is quite frequent in EP, especially in some more formal physical uses and metaphorical examples (ex. 38);

- The FLOw domain is extremely rich in EP where a general motion verb 'correr' (run) is used (ex. 39a below). Even in these cases the "poor" AQUA-motion domains maintain their unique AQUA-motion verb, alternatively with some other Motion synonyms (ex. 39b) (cf. Batoréo, in press).

(39) (a) (EP) Água/ lágrimas/ sangue/ saliva corre(m.)

Water/tears/ blood/saliva un(s)/drip(s).

(b) (Pl) Woda/ tzy/ krew/ ślina

Water/tears/ blood/ saliva

ptynie (cieknie, leje się).

$\operatorname{run}(\mathrm{s}) / \operatorname{drip}(\mathrm{s})$.

\section{Conclusions}

In the present paper it was our aim to discuss parameters of the AQUA-motion domain, illustrating the discussion mainly with European Portuguese examples in contrast with other typologically different languages. The parameters discussed were (i) the nature of a moving Figure, (ii) the nature of Motion (passive vs. active, directed vs. non-directed, type of Motion (e. g. Flowing) and Containment), and (iii) the nature of the metaphorical projection (AERO-motion and abstract domains). Basing our discussion on EP present-day language usage from electronic corpora available on the Internet our aim was to show evidence that languages may differ in predictable and regular ways in the lexicon and in the way they conceptualize the reality they live in.

\section{AQUA-motion parameters}

The basic parameters within the AQUA-motion domain are of a conceptual and semantic character, specifying:

- the Figure (human, vessels and animals)

- the Ground (water, air, states of mind, abstract media)

- the Manner in which Motion is focused

- active (self-propelled/ driven by current) vs. passive

- directed vs. non-directed (often neutralized)

- contained vs. non-contained 
- movement within the water vs. on the surface

- movement of liquid itself.

\section{AQUA-motion domains}

The basic tri-partition into SWIMMING, SAILING and FLOATING domains proposed in the studies of Majsak, Rahilina and Lander (2003, 2005, 2007) was broadly confirmed for EP.

The analysis showed the EP AQUA-motion domain is close to a rich system, especially in the SAILING area.

Following the Dutch typological proposal (Divjak \& Lemmens, 2007), the CONTAINMENT, MERSION and FLOW domains were taken into consideration in $\mathrm{EP}$, as showing some lexical specificities, contrasting intralinguistically with other domains and interlinguistically with other languages.

\section{Metaphorical projection (AERO-motion and abstract domains)}

Very regular well structured metaphorical processes were confirmed for all the domains - as illustrated in the case of the prototypical verbs 'nadar', 'navegar' and 'flutuar' - to express smooth movement of gliding or flowing where the Ground is no longer of a liquid type, referring to physical movement in the air/space, in mental states, in social life, politics, financial activity, the arts, etc.

Other metaphorical extensions were also observed, showing strong restrictions in the usage of particular verbs.

Some restrictions were also observed both for physical and metaphorical occurrences on conceptual, semantic, pragmatic and even syntactic levels, as well as in tendencies shown in general for metaphorical extension of the basic meaning.

\section{References}

Arad, M. (2007). Some aspects of the Hebrew verb saxah (swim). In T.A. Majsak, E.V Rahilina (Eds.), Glagoly dviženiâ v vode: leksičeskaâ tipologiâ (pp. 498-508). Moskva: Indrik.

Atkins, S. \& Fillmore, Ch. (2000). Describing polysemy: the case of crawl. In Y. Ravin \& C. Leacock (Eds.), Polysemy: Linguistic and Computational Approaches (pp. 91-110). Oxford: Oxford University Press.

Batoréo, H.J. (2000). Expressão do espaço no Português Europeu: contributo psicolinguístico para o estudo da linguagem e cognição. PhD Dissertation. Lisboa: Fundação Calouste Gulbenkian.

Batoréo, H. J. (2007). Lexical typology of AQUA-motion lexicon: The case of European Portuguese. Paper presented at the 10th International Cognitive Linguistic Congress, Kraków, 15-20 July, 2007.

Batoréo, H. J. (in press a). “Quando os portugueses correm, os polacos nadam?”. Domínio de movimento em água (AQUA- motion) em Português Europeu 
e Polaco: Contribuição para Tipologia Lexical. Paper presented at the Diálogos com a Lusofonia Symposium, Warsaw, December 2007. Diacrítica.

Batoréo, H.J. (in press b). Expressão do Movimento em Água (AQUA-motion) em Português Europeu: Contribuição para tipologia lexical. Revista de Linguística da Universidade Federal do Rio de faneiro.

Batoréo, H.J., Pires, A., Macedo, I., \& Casadinho, M. (2007). "Claro como água!" - Contribuição para a tipologia lexical dos verbos de movimento em água (AQUA- motion). Textos seleccionados do XXII Encontro da Associação Portuguesa de Linguística, 2007, 127-140.

Bybee, J. (1985). Morphology: A Study of the relation between meaning and form. Amsterdam: Benjamins.

Bybee, J., Perkins, R., \& Pagliuca, W. (1994). The evolution of grammar: Tense, aspect and modality in the languages of the world. Chicago: University of Chicago Press.

Casadinho, M.M. (2007). "Navegar é preciso!" Os verbos de movimento AQUA-motion do tipo NAVEGAR. Aspectos linguísticos, cognitivos e traductológicos. MA dissertation. Lisboa: Universidade Aberta.

Divjak, D. \& Lemmens, M. (2007). Lexical conflation patterns in Dutch AQUA -motion verbs. In T.A. Majsak, E.V Rahilina (Eds.), Glagoly dviženiâ v vode: leksičeskaâ tipologiâ (pp. 152-174). Moskva: Indrik.

Koch, P. (2001). Lexical typology from a cognitive point of view. In M. Haspelmath, E. König, W. Oesterreicher, \&W. Raible (Eds.), Language typology and language universals: An international handbook (pp. 1142-1178). Berlin: de Gruyter.

Lander, Y., Maisak, T.A., \& Rakhilina, E.V. (2005). Motion in a liquid medium (AQUAmotion): towards lexical typology. Paper presented at the 21st Scandinavian Conference of Linguistics, Trondheim, June 1-4, 2005.

Lander, Y., Maisak, T.A., \& Rakhilina, E.V (in press). Domains of aqua-motion: a case study in lexical typology. In E. van der Zee \& M. Dimitrova-Vulchanova (Eds.), Motion encoding in language and space. Oxford: Oxford University Press.

Majsak, T.A. (2007). Glagoly peremeŝeniâ v vode v portugal'skom âzyke. In T.A. Majsak, E.V Rahilina (Eds.), Glagoly dviženiâ v vode: leksičeskaâ tipologiâ (pp. 198-230). Moskva: Indrik.

Majsak, T.A. \& Rahilina, E.V. (2003). Tipologiâ sistem glagol'noj leksiki: dviženie v vode. In Grammatičeskie kategorii: ierarhii, svâzi, vzaimodejstvie. Materialy meždunarodnoj naučnoj konferencii, St. Petersburg, 22-24.11.2003 (pp. 89-91). St. Petersburg: ILS RAS.

Majsak, T.A. \& Rahilina, E.V. (2007). Glagoly dviženiâ i nahoždeniâ v vode: leksičeskie sistemy i semantičeskie parametry. In T.A. Majsak, E.V Rahilina (Eds.), Glagoly dviženiâ v vode: leksičeskaâ tipologiâ (pp. 27-75). Moskva: Indrik.

Newman, J. (Ed.) (1997). The linguistics of giving. Amsterdam: Benjamins.

Newman, J. (Ed.) (2002). The linguistics of sitting, standing, and lying. Amsterdam: Benjamins. 
Pires, A. (2007). "Como peixe na água!" Contribuição para a tipologia lexical dos verbos de movimento em água (Aqua-motion) do tipo FLUTUAR. Retrieved from http://www.clul.ul.pt/artigos/pires angelina.pdf (n.d.).

Prokofieva, I.A. (2007). Peremescenije v vode I peremiscenije vody: flagoly płynąć/ pływać (plyt'/plavat') v polskom jazyke. In T.A. Majsak, E.V Rahilina (Eds.), Glagoly dviženiâ v vode: leksičeskaâ tipologiâ (pp. 305-314). Moskva: Indrik.

Talmy, L. (1975). Semantics and syntax of motion. In J.P. Kimball (Ed.), Syntax and semantics. Vol. 4 (pp. 181-238). New York: Academic Press.

Talmy, L. (1983). How languag structures space. In H.L. Pick Jr. \& L.P. Acredolo (Eds.), Spatial orientation: Theory, research and application (pp. 225-282). New York: Plenum Press.

Talmy, L. (1985). Lexicalisation patterns: Semantic structure in lexical forms. In T. Shopen (Ed.), Language typology and syntactic description, vol. III, Grammatica categories and the lexicon (pp. 57-149). Cambridge: Cambridge University Press.

Talmy, L. (2000). Toward a cognitive semantics. 2 vols. Cambridge, MA: The MIT Press.

Wierzbicka, A. (1991). Cross-cultural pragmatics: the semantics of human interaction. Berlin: Mounton de Gruyter.

Wierzbicka, A. (1992). Semantics, culture and cognition: Universal human concepts in culture-specific configurations. New York: Oxford University Press.

\section{Appendix: CORPORA}

Centro de Linguística da Universidade de Lisboa $\Rightarrow$ [http://www.clul.ul.pt] Instituto Camões $\Rightarrow$ [http://www.institutocamoes.pt/escritores/camoes/lusiadas.htm] Linguateca $\Rightarrow$ [http://www.linguateca.pt/]

Corpus: CETEMPúblico 1.7 anotado 2.0

Corpus: Natura/Publico anotado v. 3.3

Corpus: Natura/Diário do Minho anotado v. 2.4

Corpus: FrasesPP anotado2 v. 4.2

Corpus: Corpus DiaCLAV anotado v. 1.3

Corpus: Corpus Avante! anotado v. 1.3

Corpus: Corpus CoNE anotado v1.0

Corpus: Corpus ClassLPPE anotado v.1.0

Corpus: Museu da Pessoa anotado v1.0

Corpus: Corpus CONDIVport anotado v1.0 